\title{
A Study on the Higher Education System in India and Factors Affecting the Choice of Teaching Career in IT Education
}

\author{
Sweta Bhattacharya \\ Assistant Professor, School of Information Technology and Engineering, VIT University, Vellore, Tamil Nadu - 632014, India \\ sweta.b@vit.ac.in
}

\section{Doi:10.5901/mjss.2015.v6n4s1p62}

\section{Abstract}

India is a country with high educational values and is considered as a country with an asset of technically sound, motivated and hardworking student strength and dedicated faculty members. But at the same time, there exists shortage of such talented faculty members across different Universities and affiliated Institutes in India. The research objective of the paper is to analyse the different factors that guide teaching career decisions among IT engineering graduates and post-graduates and to find the most significant factors which influences such career choices. The statistical analysis presented in the paper is based on a Survey conducted on the Graduate and Post-Graduate students in a private University in India. The factors considered in the study are Motivation, Perception, Interest, Professional and Financial Security, Career Choice based on Knowledge and skill and finally Inclination towards research. The study reveals the effect of Gender on the perception of teaching career choice and also shows the existence of significantly different effect of the Semester/year of study on the different factors that affects teaching career. The study also reviews the present higher education scenario in India and correlates the factors that affect faculty shortage and career choice based on present Indian perspective. Based on the statistical analysis results the paper provides list of recommendations which would be beneficial and would encourage more individuals to choose a teaching career.

Keywords: Higher Education, Teaching Career, Career Choice, Faculty shortage,

\section{Introduction: Higher Education in India}

The economic growth of a country is highly dependent of the education system and infrastructure of the same. "The current market of higher education in India is about $\$ 40$ billion per year" (Deepti Gupta, Navneet Gupta, 2012). The UGC Annual Report 2013-14 reveals interesting facts about the growth of higher education system in India. India had 20 Universities and 500 colleges with strength of 2.1 lakh students at the time of Independence. This number has increased 37 times in terms of Degree Awarding Universities and 113 times in terms of the formal higher education system since the time of the Independence of India. The present reports indicate that as of 2013-14 there are 666 Universities and University level higher education Institutes in India out of which 313 are State Universities, 175 State Private Universities, 45 Central Universities, 129 Deemed Universities and four Institutes established under the State Legislature Act. The total numbers of Colleges in India is 39,671 (Deepti Gupta, Navneet Gupta, 2012). India has also seen consistent growth in terms of student enrolment for the past three decades and the present academic year has an enrolment of 237.65 lakhs students in different courses at various colleges, Universities and higher education Institutions ( $60^{\text {th }}$ Annual Report, UGC, 2013-14). Table 1 shows the trend of student enrolment for the past two decades in India.

Table 1: Year wise enrolment in higher education Institutes in India (60th Annual Report, UGC, 2013-14)

\begin{tabular}{|c|c|c|c|}
\hline Year & Total Enrolment & Increase over the preceding year & Percentage of Increase \\
\hline $1988-89$ & 4285489 & 265330 & 2.8 \\
\hline $1992-93$ & 5534966 & 532939 & 6.2 \\
\hline $1996-97$ & 6842598 & 268593 & 9.6 \\
\hline $2000-01$ & 8399443 & 348836 & 3.9 \\
\hline Year & Total Enrolment & Increase over the preceding year & Percentage of Increase \\
\hline $2004-05$ & 11038543 & 836562 & 4.2 \\
\hline $2008-09$ & 15768417 & 1368036 & 7.6 \\
\hline $2012-13$ & 22302938 & 1975460 & 8.7 \\
\hline $2013-14$ & 23764960 & 1462022 & 8.9 \\
\hline
\end{tabular}


The student enrolment of the present years have revealed that majority (85\%) of the students got enrolled in various undergraduate level courses in various colleges and Universities in India. The enrolment at the post-graduation level was $12 \%$ and a very nominal percentage $(0.85 \%)$ of students preferred to choose research as a prospective career path. The level wise enrolment in various Universities and Colleges in India are shown in Table 2 (60 th Annual Report, UGC, 201314).

Table 2: Level wise student enrolment in Higher Education Institutes in India (60 th Annual Report, UGC, 2013-14)

\begin{tabular}{|l|c|c|c|c|}
\hline Level & $\begin{array}{c}\text { University Departments } \\
\text { and Colleges }\end{array}$ & $\begin{array}{c}\text { Affiliated } \\
\text { Colleges }\end{array}$ & $\begin{array}{c}\text { Total } \\
\text { Percentage }\end{array}$ & $\begin{array}{c}\text { Percentage in Affiliated } \\
\text { Colleges }\end{array}$ \\
\hline Graduate & 2125559 & 18104033 & 85.12 & 89.49 \\
\hline Post - Graduate & 774557 & 2160432 & 12.35 & 73.61 \\
\hline Research & 156845 & 43885 & 0.85 & 21.86 \\
\hline Diploma/Certificate & 156909 & 242740 & 1.68 & 60.74 \\
\hline
\end{tabular}

\section{Faculty Crunch in Academic Institutions}

Faculty crunch has been one of the most gleaming issues in India for the past few decades. As per the statistical analysis done by the Indian Institute of Technology, the premier Institutes in India will require more than a decade to reach the ideal student-faculty ratio. The huge shortage of faculty across India has resulted in compromising of the overall quality of technical education. As a result the existing faculty population are over-burdened, unable to find adequate time for the preparation of teaching - learning sessions and also have immense scarcity of time to invest in quality research activities. The present student to faculty ratio and amount of vacant positions in the leading IIT's across the country reveal interesting statistics as shown in Table 3. (Hemali Chhapia, 2013). The data revealed is considerably alarming and force us to conduct study on the factors that contribute to the faculty crunch and also motivates us to find the relevant reasons for young aspiring graduates to choose or reject teaching as a prospective career path.

Table 3: Sanctioned, Filled and Vacant Position in the IIT's in India (Hemali Chhapia, 2013)

\begin{tabular}{|c|c|c|c|}
\hline Institute & $\begin{array}{c}\text { Sanctioned Faculty Positions } \\
\text { as of } \mathbf{2 0 1 3}\end{array}$ & $\begin{array}{c}\text { Filled } \\
\text { positions }\end{array}$ & $\begin{array}{c}\text { Vacant Positions (Faculty- } \\
\text { Student Ratio) }\end{array}$ \\
\hline IIT - Kharagpur & 1000 & 572 & $428(1: 17)$ \\
\hline IIT - Bombay & 832 & 565 & $267(1: 15)$ \\
\hline IIT - Madras & 800 & 506 & $294(1: 19)$ \\
\hline IIT - Kanpur & 570 & 352 & $218(1: 17)$ \\
\hline
\end{tabular}

\begin{tabular}{|l|c|c|c|}
\hline Institute & $\begin{array}{c}\text { Sanctioned Faculty } \\
\text { Positions as of 2013 }\end{array}$ & $\begin{array}{c}\text { Filled } \\
\text { positions }\end{array}$ & $\begin{array}{c}\text { Vacant Positions (Faculty- } \\
\text { Student Ratio) }\end{array}$ \\
\hline IIT - Delhi & 748 & 423 & $325(1: 18)$ \\
\hline IIT - Guwahati & 451 & 334 & $117(1: 13)$ \\
\hline IIT - Roorkee & 753 & 393 & $360(1: 20)$ \\
\hline Total (Across India) & 6522 & 3904 & 2618 \\
\hline
\end{tabular}

\section{Major Contributors towards Faculty Shortage.}

There presently exists a huge difference in the demand and supply ratio of the number of higher education faculty in India. Moreover, the metrics to calculate the amount of faculty shortage is also incorrect and biased and hence fail to reflect the accurate shortage amount at a given point of time. Faculty shortage is normally estimated by administering the total number of vacant position in an educational Institute with respect to the total number of sanctioned positions in the Institute. The sanctioned positions are ideally considered as the "demand" and filled positions as "supply/supplied" and vacant positions reflect the gap between demand and supply. But factors such as demographic trends, economic factors, desired values of income and employment which are subject to continuous change in time remains unconsidered and hence the entire estimations ends up being incorrect and biased (Chiranjib Sen, 2011). The faculty strength and percentage of faculty in different cadres in various University and University Level Colleges in India are shown in Table 4 and Table 5. 
Table 4: Faculty Strength and Staff Distribution in University and University Level Colleges: 2013 - 14 (Excluding Affiliated Colleges) (60th Annual Report, UGC, 2013-14)

\begin{tabular}{|c|c|c|c|c|c|}
\hline Year & Professors & $\begin{array}{c}\text { Readers/Associate Professors/Lecturers } \\
\text { (Selection Grade) }\end{array}$ & $\begin{array}{c}\text { Lecturers (Senior } \\
\text { Scale) }\end{array}$ & $\begin{array}{c}\text { Assistant } \\
\text { Professors/Lecturers }\end{array}$ & $\begin{array}{c}\text { Tutor/ } \\
\text { Demonstrators }\end{array}$ \\
\hline $2013-14$ & $\begin{array}{c}30272 \\
(16.69)\end{array}$ & $46102(25.41)$ & $17238(9.50)$ & $79372(43.75)$ & $8434(4.65)$ \\
\hline
\end{tabular}

Table 5: Cadre Wise Percentage of Faculty: 2013 - 2014(Including Affiliated Colleges) (60th Annual Report, UGC, 201314)

\begin{tabular}{|l|c|}
\hline Category & Percentage \\
\hline Tutor/Demonstrators & 3.17 \\
\hline Assistant Professors/Lecturers & 51.07 \\
\hline Lecturers (Senior Scale) & 10.50 \\
\hline Readers/Associate Professors/Lecturers (Selection Grade) & 26.10 \\
\hline Professors and Equivalent & 9.16 \\
\hline
\end{tabular}

Numerous studies have been conducted to understand the reasons behind faculty shortage throughout the globe. The study by Grace G., (1991) revealed the demotivating factors for graduate and post graduate students not to choose teaching as a career. The study revealed that majority of the post graduate students after completion of their courses choose corporate positions as a possible career choice and do not consider teaching or research as a career path with prospective growth opportunity. There are multiple reasons which act as catalyst for low interest, motivation, perception and dissatisfaction towards the choice of teaching career. The major contributors towards faculty shortage are:

- Fund shortage in Higher education Institutes

- Heterogeneous and Unstructured pay scale and incentive methods

- Slow and biased professional growth opportunities

- Lack of autonomy

- Political and work environment related factors

- Uncontrolled student enrolment

\section{Factors Affecting the Choice of Teaching Career}

Teaching is often considered one of the most prestigious, responsible and challenging professions in the society. But recent faculty crunch in various academic Institutes compels one to study the major factors that affect the choice of teaching career. The study by Bowen and Schuster (1986), Braskamp and Ory (1994) categorizes the role of a faculty into five major categories: Instruction and Teaching, Research and Innovative activities, Public Service, Institutional and Citizenship and Operational. In an ideal situation, a faculty is expected to perform all the five major activities which would distinguish the teaching credibility of a higher education teacher and a school teacher.

The study by Richardson, R. and Watt, H. (2005) discussed the various factors that generally affected career choice of engineering graduates and post graduates. According to the study, career choices of students are normally guided by three major factors namely Social, Technical and External Factors. Social Reasons deal with the growth and improvement of the society and students interested to work for a social cause are normally inclined and guided by social factors and choose similar professions. Intrinsic reasons guide the student to choose a career based on the knowledge domain, expertise and skills. Extrinsic factors relate to benefits of holidays, lower stress factors, remuneration, and social prestige. Hence students who intend to work in a stress free at the same time responsible and noble professional environment choose teaching or similar type of profession.

The study by Doren et. al. (1991) conducted in Center for Technological Education Holon (CTEH) revealed that out of a sample size of 171 engineering graduates; only $22 \%$ opted to choose a teaching career while majority (78\%) went ahead with careers in other engineering and technical sectors.

The study by Gokul Das V.K (2010) in a southern Indian perspective discussed the difference in career choice based on Gender. The study revealed that factors such as working hours, low stress levels were the main reason for female graduates to choose teaching profession. The majority of the female graduates chose the profession in spite of comparatively lower salary and growth opportunities because they were often the secondary financial contributor in the 
family and wanted to work in a profession that allowed space and ability to easily manage professional and financial life.

The study by Shehnaz Tehseen and Noor UI Hadi (2015) studied the factors that influence teacher performance and retention. The conceptual framework discussed in the study mentioned Motivation, Teacher Characteristics, Student Body Characteristics, Institutes Contextual Factors and Teacher Turnover, Administrative Support, Staff Relations and Facilities as the major reason for faculty performance and major factors that affected retention of faculty members.

\section{Methodology: Data Collection and Survey Instrument}

A survey was conducted to understand the impact of various factors that affected and influenced the choice of teaching career. The survey instrument used was a questionnaire which was distributed among a population of graduate and post graduate students studying Information Technology in a private University in India. The first part of the questionnaire consisted of demographic questions related to Program, Year/Semester of study, Age, Gender. The second part of the questionnaire consisted of the various factors which contributed to the choice of teaching career. Each factors consisted of 10-12 statements with a five point Likert scale. The detailed abbreviations of the Likert scale were Strongly Agree -5 , Somewhat Agree - 4, Neither - 3, Somewhat Disagree - 2, Strongly Disagree -1 . The questionnaire was distributed among 400 undergraduate and graduate students and 150 students responded and completed the questionnaire. The majority of the respondents were Male (63\%) and female respondents were 37\%. The student belonged to three different age categories keeping in mind the fact that the respondents were of Graduate and Post Graduate level. $32 \%$ of the Respondents were aged between $18-22$ years, $58 \%$ belong to the age group of $23-27$ years and $10 \%$ of the students were of 28 years and above age. As mentioned the students primarily B.Tech and M.Tech students studying Information Technology program and were First year, Second Year and Final Year (Third/Fourth year) students. Both Descriptive and Inferential statistical data analysis was conducted on the collected data set in order to get a concrete conclusion. The demographic details of the respondents are represented in the following Table 6.

Table 6: Demographic Information

\begin{tabular}{|c|c|c|c|}
\hline Demographic Variables & Sub Category of Variables & Number of Respondents & Percentage \\
\hline \multirow{2}{*}{ Gender } & Male & 95 & 63 \\
\hline & Female & 55 & 37 \\
\hline \multirow{3}{*}{ Age } & $18-22$ years & 48 & 32 \\
\hline & $23-27$ years & 87 & 58 \\
\hline & 28 years and above & 15 & 10 \\
\hline \multirow{2}{*}{ Program of Study } & B.Tech & 71 & 47 \\
\hline & M.Tech & 79 & 53 \\
\hline \multirow{3}{*}{ Year/Semester of Study } & First Year & 27 & 18 \\
\hline & Second Year & 12 & 8 \\
\hline & Third and Beyond & 111 & 74 \\
\hline
\end{tabular}

\section{Data Analysis}

Minitab 17.0 version was used to analyse the data. There were seven major factors which were considered in the study and constituted the list of statements in the questionnaire. The factors considered in the study were "Motivation", "Perception", "Interest", "Professional and Financial Security", "Career Choice based on Knowledge and IT skill" and Inclination towards Research". The descriptions of the factors are mentioned in the following Table 7.

Table 7: List of factors that affected choice of career in Teaching

\begin{tabular}{|l|l|}
\hline \multicolumn{1}{|c|}{ Factors } & Description \\
\hline Motivation & Motivation from Family \\
& Motivation from Parents and Teachers \\
& Respect from Society \\
& Sense of Responsibility \\
& Motivation to balance professional and personal life \\
& Motivation to work with young and creative minds \\
\hline
\end{tabular}




\begin{tabular}{|c|c|}
\hline Factors & Description \\
\hline Perception & $\begin{array}{l}\text { Ability to contribute to the future of the society } \\
\text { Ability to make a difference and bring positive changes } \\
\text { Ability to mould the younger generation positively } \\
\text { Immense sense of professional satisfaction } \\
\text { Enjoyment in learning and sharing of knowledge } \\
\text { Self-actualization and fulfilment } \\
\text { Ability to work with freedom and autonomy }\end{array}$ \\
\hline Interest & $\begin{array}{l}\text { Natural Interest in Teaching } \\
\text { Excellent leadership capability and interest to become a public speaker } \\
\text { Interest in a significant career } \\
\text { Interest to work in a people centric environment } \\
\text { Interest to encourage and develop new ideas } \\
\text { Interest to work in a non-hectic, healthy and hassle free environment } \\
\text { Interest to work with a diverse population } \\
\text { Interest to work in a deadline-free and less stringent environment }\end{array}$ \\
\hline Professional and Financial Security & $\begin{array}{l}\text { Job security } \\
\text { Commensurate and consistent salary structure } \\
\text { Rare chances of sudden layoffs } \\
\text { Excellent Retirement Benefits } \\
\text { Professional Flexibility } \\
\text { Excellent Retention Policies } \\
\text { Steady and Low Risk Growth Opportunities } \\
\text { Appealing Personal and Healthcare Benefits } \\
\text { Satisfactory Financial Benefits } \\
\text { Performance based and unbiased appraisals }\end{array}$ \\
\hline Career Choice based on Knowledge and IT Skill & $\begin{array}{l}\text { Ability to teach computational concepts } \\
\text { Strong Fundamental Concepts } \\
\text { Expertise in Hardware and Software technologies } \\
\text { Adequate knowledge to implement IT } \\
\text { Ability to integrate IT based solutions to the user environment } \\
\text { Adherence to best practices and standards }\end{array}$ \\
\hline Inclination Towards Research & $\begin{array}{l}\text { Interest to do research } \\
\text { Ability to publish research papers } \\
\text { Ability to work and implement innovative research ideas and concepts } \\
\text { Ability to balance teaching and research } \\
\text { Ability to get professional growth for research contributions } \\
\text { Ability to introduce new research findings in the teaching of courses }\end{array}$ \\
\hline
\end{tabular}

\subsection{Correlation Analysis}

Correlation analysis was conducted to find the strength or relationship between the different factors or variables. The motivational factor was highly correlated with the Perception (0.76) and Interest factor (0.72). This indicated that if a student is highly motivated towards the teaching profession, his perception about the profession would be good and he would feel interested to choose a career path in teaching. The motivational factor was also considerably highly correlated with the Inclination towards Research factor $(0.30)$ in comparison to the other factors used in the study. This indicated that motivation towards academic career affects inclination towards research and ability to perform research and developmental activities and include innovative ideas in the teaching - learning environment. The Perception factor was highly correlated with the Interest factors which revealed the fact that positive perception towards the teaching profession would influence the natural interest to teach and remain the profession. On the contrary the Career choice based on Knowledge and IT Skill was scarcely correlated with the Professional and Financial Security Factor (0.03). This revealed the fact that if a student had genuine interest in the profession based on his knowledge domain and IT skills, the financial factors and professional security factors would hardly have any impact on career related decisions. Similarly Motivation, Perception and Interest related factors had low correlation values with the Professional and Financial Security factor which indicated that if a student had high motivation, perception and interest, the professional and financial factors of the profession would not have much impact keeping in mind the fact that corporate job positions would have more attractive salary packages and faster growth opportunities. 


\subsection{Analysis of Variance (ANOVA)}

Analysis of Variance (ANOVA) test was conducted to understand the influence of Gender, Age, Program, Semester /Year of Study on the different factors that contributed towards the choice of teaching career. In case of Gender, it was found there exists significant difference in the perception of teaching career among male and female students $(F=5.79, P=$ 0.017). This interprets the fact that in Indian perspective female students were more inclined towards teaching profession due the sense of social responsibility and their natural interest to nurture young minds and make positive changes to the society. Similarly, the ability to work in an autonomous environment would give them more freedom and space to balance professional and personal life. The test also reflected that there was no significant difference in terms of gender in case of motivation, interest, professional and financial security; career choice based on knowledge and IT skill, and individuals' inclination towards research factors. The analysis of variance result is shown in Table 8.

Table 8: ANOVA Test Results representing Influence of Gender

\begin{tabular}{|c|c|c|c|c|c|c|}
\hline \multirow[t]{4}{*}{ Motivation } & Source & DF & SS & MS & F-Value & P-Value \\
\hline & Gender & 1 & 260.4 & 260.4 & 1.23 & 0.269 \\
\hline & Error & 148 & 31267.9 & 211.3 & & \\
\hline & Total & 149 & 31528.3 & & & \\
\hline \multirow[t]{4}{*}{ Perception } & Source & DF & SS & MS & F-Value & P-Value \\
\hline & Gender & 1 & 998.2 & 998.2 & 5.79 & 0.017 \\
\hline & Error & 148 & 25512.5 & 172.4 & & \\
\hline & Total & 149 & 26510.7 & & & \\
\hline \multirow[t]{4}{*}{ Interest } & Source & DF & SS & MS & F-Value & P-Value \\
\hline & Gender & 1 & 312.7 & 312.7 & 2.37 & 0.126 \\
\hline & Error & 148 & 19507.1 & 131.8 & & \\
\hline & Total & 149 & 19819.8 & & & \\
\hline \multirow[t]{4}{*}{ Professional \& Financial Security } & Source & DF & SS & MS & F-Value & P-Value \\
\hline & Gender & 1 & 27.71 & 27.71 & 0.90 & 0.345 \\
\hline & Error & 148 & 4577.07 & 30.93 & & \\
\hline & Total & 149 & 4604.77 & & & \\
\hline \multirow[t]{4}{*}{ Career Choice based on Knowledge and IT Skill } & Source & DF & SS & MS & F-Value & P-Value \\
\hline & Gender & 1 & 99.03 & 99.03 & 3.63 & 0.059 \\
\hline & Error & 148 & 4040.14 & 27.30 & & \\
\hline & Total & 149 & 4139.17 & & & \\
\hline \multirow[t]{4}{*}{ Inclination towards Research } & Source & DF & SS & MS & F-Value & P-Value \\
\hline & Gender & 1 & 12.86 & 12.86 & 0.23 & 0.634 \\
\hline & Error & 148 & 8355.97 & 56.46 & & \\
\hline & Total & 149 & 8368.83 & & & \\
\hline
\end{tabular}

\subsection{Influence of Age on the various factors affecting choice of teaching career}

ANOVA test was conducted to find if there was significant difference among different age groups which affected the various factors to choose teaching profession. The results revealed that there is no significant difference $(P>0.05)$ among different age groups to accept or reject a teaching career. This indicates the fact that the age group of students do not affect their interest towards choice of teaching career. Motivation and Interest in the teaching profession might be prominent at a very young age or even later in the career when a student is much matured regardless of the age factor while other components might have more significant influence. The analysis of variance result is shown in Table 9.

Table 9: ANOVA Test Results representing Influence of Age

\begin{tabular}{|l|l|c|c|c|c|c|}
\hline Motivation & Source & DF & SS & MS & F-Value & P-Value \\
\cline { 2 - 8 } & Gender & 3 & 1079 & 359.6 & 1.72 & 0.165 \\
\cline { 2 - 8 } & Error & 146 & 30450 & 208.6 & & \\
\cline { 2 - 7 } & Total & 149 & 31528 & & & \\
\hline
\end{tabular}




\begin{tabular}{|l|l|c|c|c|c|c|}
\hline Perception & Source & DF & SS & MS & F-Value & P-Value \\
\cline { 2 - 8 } & Gender & 3 & 740.9 & 247.0 & 1.40 & 0.245 \\
\cline { 2 - 8 } & Error & 146 & 25769.8 & 176.5 & & \\
\cline { 2 - 8 } & Total & 149 & 26510.7 & & & \\
\hline \multirow{5}{*}{ Interest } & Source & DF & SS & MS & F-Value & P-Value \\
\cline { 2 - 8 } & Gender & 3 & 565.0 & 188.3 & 1.43 & 0.237 \\
\cline { 2 - 8 } & Error & 146 & 19254.8 & 131.9 & & \\
\cline { 2 - 8 } & Total & 149 & 19819.8 & & & \\
\hline Professional \& Financial Security & Source & DF & SS & MS & F-Value & P-Value \\
\cline { 2 - 7 } & Gender & 3 & 94.26 & 31.42 & 1.02 & 0.387 \\
\cline { 2 - 8 } & Error & 146 & 4510.51 & 30.89 & & \\
\cline { 2 - 7 } & Total & 149 & 4604.77 & & & \\
\hline Career Choice based on Knowledge and IT Skill & Source & DF & SS & MS & F-Value & P-Value \\
\cline { 2 - 7 } & Gender & 3 & 50.26 & 16.75 & 0.60 & 0.617 \\
\cline { 2 - 7 } & Error & 146 & 4088.92 & 28.01 & & \\
\cline { 2 - 7 } & Total & 149 & 4139.17 & & & \\
\hline Inclination towards Research & Source & DF & SS & MS & F-Value & P-Value \\
\hline & Gender & 3 & 193.8 & 64.59 & 1.15 & 0.330 \\
\cline { 2 - 7 } & Error & 146 & 8175.1 & 55.99 & & \\
\cline { 2 - 7 } & Total & 149 & 8368.8 & & & \\
\hline
\end{tabular}

\subsection{Influence of the Program of Study on choice of teaching career}

ANOVA test was conducted to find if there exists a significant difference among B.Tech and M. Tech students towards the choice of a teaching career. The results revealed the program of study does not affect the choice of career or their inclination towards a teaching profession $(P>0.05)$. The analysis of variance result is shown in Table 10.

Table 10: ANOVA Test Results representing Influence of Program of Study

\begin{tabular}{|c|c|c|c|c|c|c|}
\hline \multirow[t]{4}{*}{ Motivation } & Source & DF & SS & MS & F-Value & P-Value \\
\hline & Gender & 1 & 30.5 & 30.47 & 0.14 & 0.706 \\
\hline & Error & 148 & 31497.8 & 212.82 & & \\
\hline & Total & 149 & 31528.3 & & & \\
\hline \multirow[t]{4}{*}{ Perception } & Source & DF & SS & MS & F-Value & P-Value \\
\hline & Gender & 1 & 234.8 & 234.8 & 1.32 & 0.252 \\
\hline & Error & 148 & 26275.9 & 177.5 & & \\
\hline & Total & 149 & 26510.7 & & & \\
\hline \multirow[t]{4}{*}{ Interest } & Source & DF & SS & MS & F-Value & P-Value \\
\hline & Gender & 1 & 417.4 & 417.4 & 3.18 & 0.076 \\
\hline & Error & 148 & 19402.4 & 131.1 & & \\
\hline & Total & 149 & 19819.8 & & & \\
\hline \multirow[t]{4}{*}{ Professional \& Financial Security } & Source & DF & SS & MS & F-Value & P-Value \\
\hline & Gender & 1 & 14.66 & 14.66 & 0.47 & 0.493 \\
\hline & Error & 148 & 4590.11 & 31.01 & & \\
\hline & Total & 149 & 4604.77 & & & \\
\hline \multirow[t]{4}{*}{ Career Choice based on Knowledge and IT Skill } & Source & $\mathrm{DF}$ & SS & MS & F-Value & P-Value \\
\hline & Gender & 1 & 1.01 & 1.010 & 0.04 & 0.849 \\
\hline & Error & 148 & 4138.16 & 27.961 & & \\
\hline & Total & 149 & 4139.17 & & & \\
\hline \multirow[t]{4}{*}{ Inclination towards Research } & Source & DF & SS & MS & F-Value & P-Value \\
\hline & Gender & 1 & 0.85 & 0.8487 & 0.02 & 0.903 \\
\hline & Error & 148 & 8367.98 & 56.5404 & & \\
\hline & Total & 149 & 8368.83 & & & \\
\hline
\end{tabular}




\subsection{Influence of Semester/Year of Study on the choice of teaching career}

ANOVA test was conducted to find if there were any variations in terms of Semester/Year of study on the factors that contributed towards the choice of career in teaching. The results revealed that there existed difference in terms of Semester/Year of study which impacted Motivation $(F=21.01, P=0.000)$, Perception $(F=22.39, P=0.000)$, Interest $(P$ $=13.59, P=0.000)$ and Career Choice of IT graduates based on their Knowledge and IT skill $(F=4.17, P=0.017)$. The analysis of variance result is shown in Table 11.

Table 11: ANOVA Test Results representing Influence of Semester/Year of Study

\begin{tabular}{|c|c|c|c|c|c|c|}
\hline \multirow[t]{4}{*}{ Motivation } & Source & DF & SS & MS & F-Value & P-Value \\
\hline & Gender & 2 & 7009 & 3504.4 & 21.01 & 0.000 \\
\hline & Error & 147 & 24520 & 166.8 & & \\
\hline & Total & 149 & 31528 & & & \\
\hline \multirow[t]{4}{*}{ Perception } & Source & DF & SS & MS & F-Value & P-Value \\
\hline & Gender & 2 & 6190 & 3095.2 & 22.39 & 0.000 \\
\hline & Error & 147 & 20320 & 138.2 & & \\
\hline & Total & 149 & 26511 & & & \\
\hline \multirow[t]{4}{*}{ Interest } & Source & DF & SS & MS & F-Value & P-Value \\
\hline & Gender & 2 & 3092 & 1546.1 & 13.59 & 0.000 \\
\hline & Error & 147 & 16728 & 113.8 & & \\
\hline & Total & 149 & 19820 & & & \\
\hline \multirow[t]{4}{*}{ Professional \& Financial Security } & Source & DF & SS & MS & F-Value & P-Value \\
\hline & Gender & 2 & 114.1 & 57.06 & 1.87 & 0.158 \\
\hline & Error & 147 & 4490.7 & 30.55 & & \\
\hline & Total & 149 & 4604.8 & & & \\
\hline \multirow{4}{*}{ Career Choice based on Knowledge and IT Skill } & Source & DF & SS & MS & F-Value & P-Value \\
\hline & Gender & 2 & 222.0 & 111.00 & 4.17 & 0.017 \\
\hline & Error & 147 & 3917.2 & 26.65 & & \\
\hline & Total & 149 & 4139.2 & & & \\
\hline \multirow[t]{4}{*}{ Inclination towards Research } & Source & DF & SS & MS & F-Value & P-Value \\
\hline & Gender & 2 & 190.9 & 95.44 & 1.72 & 0.183 \\
\hline & Error & 147 & 8178.0 & 55.63 & & \\
\hline & Total & 149 & 8368.8 & & & \\
\hline
\end{tabular}

The results interpret the fact that the career path of student in the initial part of the study is volatile and unsure due to lack of in-depth knowledge of the domain. The students become much confident as the years progress and achieves the ability to take firm and focused decision towards the final semesters of study in the program. On the contrary, there are instances wherein the initial impression of the study in a program also guides the student to choose or reject a particular career path.

\section{Results}

The findings, interpretations and limitations of study are based on the Indian perspective and hence are guided by social, economic and cultural factors relevant to the country. The results represent the following facts:

- Motivation, Perception and Interest towards the teaching profession are highly correlated and each factor guides the other factors automatically.

- The professional and financial security related factor does not have significant impact on the choice of teaching career.

- Gender has influence on the perception of teaching career.

- The program of study does not influence choice of teaching career. Hence the general idea of post graduate students being more inclined towards teaching career cannot be proven.

- The semester/year of study has significant influence on Motivation, Perception, Interest and Career Choice based on Knowledge and IT skills. 


\section{Conclusions and Recommendations}

The study highlights the different aspects and issues related to Higher Education in India. It represents a thorough analysis of the different factors that affect and guide students to choose career in teaching. The Indian government has taken multiple initiatives to attract talented students and professional towards teaching career. Apart from these initiatives the following recommendations will enable the government to combat the faculty crunch and shortage related issues more efficiently

- More number of Universities and colleges should be given affiliation to provide quality education in minimum cost focusing more on the rural and under privileged students

- Enhance and encourage collaboration with foreign Universities in terms of research funding, training and developmental activities

- Provide tax concessions to private sector management to setup and run quality education system

- Create opportunity for teachers to collaborate and work with the industry. This will benefit the industry to get talented manpower at the same time faculty members will be able to transfer the up-to-date knowledge gained in real time from the industry to the students

- Encourage technical Institutes to focus more on human interaction related courses and ethical theories on social obligation, responsibilities.

- Provide IT infrastructure to students at all levels of the society in nominal prices

- Finally, provide competitive incentive and salary packages to the teachers to attract quality professional and retain them to continue to stay in the profession

\section{Acknowledgement}

The author of this paper would like to express appreciation towards Post Graduate Students Ms. Rajalakshmi S. and Ms. Nivetha V., at VIT University who have helped in distribution, collection of the survey questionnaires and helped immensely in conducting the survey.

\section{References}

Deepti Gupta, Navneet Gupta. (2012). Higher Education in India: Structure Statistics and Challenges. Journal of Education and Practice, $3,2,17-24$

60th Annual Report. University Grants Commission. 2013-14. (pp. 50 - 78). 2013-14

Hemali Chhapia (2013), IITs will take nearly 10 years to get to ideal teacher-student ratio. [Online] Available: http://timesofindia. indiatimes.com/home/education/news/llTs-will-take-nearly-10-years-to-get-to-ideal-teacher-studentratio/articleshow/22670998.cms (September 18, 2013)

Chiranijib Sen (2011). A Framework for Analyzing Demand and Supply of Faculty and the Quality of Higher Education, IIM Bangalore, Working Paper No. 350, 1 - 34 .

Grace G. (1991). The state and the teachers: problems in teacher supply, retention and morale, Evaluation and Research in Education, $1 \& 2,3-16$.

Bowen, H.R., Schuster, J.H. (1986). American professors: A national resource imperilled. New York: Oxford University Press.

Braskamp, L.A. Ory, J.C. (1994). Assessing Faculty Work: Enhancing Individual and Institutional Performance. San Francisco: JosseyBass.Richardson.

Richardson, R., Watt, H. (2005). I've decided to become a teacher: Influences on career change. Teaching and Teacher Education: An International Journal of Research and Studies, 21, 5, 475- 489.

Doron, R., Braunstein, A. (1991). Preference of Teaching versus Engineering Careers among Technical Education Graduates (Teacher Education). IEEE Xplore. Electrotechnical Conference Proceedings 6th Mediterranean, 2, 1514 - 1517.

Gokuldas, V.K. (2010). Factors that influence first-career choice of undergraduate engineers in software services companies, A South Indian experience. Career Development International. Emerald Group Publishing Ltd., 15, 2, 144-165.

Shehnaz Tehseen, Noor UI Hadi (2015). Factors Influencing Teachers' Performance and Retention. Mediterranean Journal of Social Sciences, 6, №. 1, 33. 